Article

\title{
Then Solomon Took a Census of All the Aliens
}

\author{
Isaac Samuel Villegas \\ Chapel Hill Mennonite Fellowship, Durham, NC 27707, USA; isaac.villegas@gmail.com
}

Received: 16 January 2019; Accepted: 20 March 2019; Published: 26 March 2019

\begin{abstract}
The citizen creates the alien. The apparatus of citizenship establishes the criteria to determine who should be counted as undocumentable and therefore alien to lawful existence in this geographical territory. Detention centers extend the carceral imagination that subtends the modern state, which has claimed ownership of a particular land and has established a legal framework to criminalize and punish peoples who are categorized as threats to its vision for society. This paper tracks with Scriptural theologies that inform mechanisms of enslavement, the shadow side of citizenship. The United States is a project in social engineering, in population control, invested in registering and monitoring and relocating human life-all of which resonate with political trajectories outlined in biblical texts. The Scriptures are not salvific on their own terms. A liberative theology begins with a political commitment of solidarity. In this paper the detention center becomes a site from which to understand the carceral power that creates the world-a political landscape echoing with biblical theologies.
\end{abstract}

Keywords: political theology; immigration; incarceration

\section{Citizens and Aliens}

"Then Solomon took a census of all the aliens who were residing in the land of Israel, after the census that his father David had taken" (2 Chron. 2:17a). In the Chronicler's narrative, King Solomon numbers the foreigners in his territory in order to monitor their existence, to track their sojourn in his land, and to allocate their bodies in his system of labor exploitation. "Seventy thousand of them he assigned as laborers, eighty thousand as stonecutters in the hill country, and three thousand six hundred as overseers to make the people work" (2 Chron. 2:18). Resident aliens are slave labor. Solomon relocates them throughout his kingdom as needed, assigning overseers from among the enslaved population to administer Israel's public work projects. The second chapter of 2 Chronicles begins with the king's penchant for forced labor. "Solomon decided to build a temple for the name of the Lord, and a royal palace for himself. Solomon conscripted seventy thousand laborers and eighty thousand stonecutters in the hill country, with three thousand six hundred to oversee them" (2 Chron. 2:1-2). His sovereignty involves converting people into numbers for the political economy's ledger.

Solomon inherits these procedures from his father, King David, who ordered a census as his reign began to unravel (1 Chron. 21:1-6; 2 Sam. 24:1-9) and later "gave orders to gather together the aliens who were residing in the land of Israel, and he set stonecutters to prepare dressed stones for building the house of God" (1 Chron. 22:2). Solomon received from David what was also passed on from the Lord who authorized Moses to keep track of people— “the whole congregation of Israelites" —with two major censuses in the book of Numbers, at the beginning and toward the end (Num. 1:1-4 and 26:1-4).

To number the people, to monitor population growth, to differentiate groups within the land-these concerns subtend a legal structure founded upon the distinction between who has rights of belonging and who can be rightfully subjugated. Counting provides the data necessary to demarcate the shape of the people, thereby positioning non-Israelite residents as alien. Within this political 
trajectory, within this biblical imagination, the law names the foreigner as an alien whose existence is at the discretion of the citizen. Aliens, as the book of Leviticus makes clear, are enslaveable:

it is from the nations around you that you may acquire male and female slaves. You may also acquire them from among the aliens residing with you, and from their families that are with you, who have been born in your land; and they may be your property. You may keep them as a possession for your children after you, for them to inherit as property. These you may treat as slaves, but as for your fellow Israelites, no one shall rule over the other with harshness (Lev. 25:44-46).

This description of the status of the foreigner and alien occurs in the Jubilee legislation which orders a season of debt forgiveness, including the liberation of indentured servants. But the liberation of Jubilee is only for Israelites. "They shall remain with you as hired or bound laborers. They shall serve with you until the year of the jubilee" (Lev. 25:40) — then they will be released from servitude because Israelites may not permanently enslave their kin. However, the same law authorizes the use of aliens as chattel-slaves, foreigners as enslaveable in perpetuity. ${ }^{1}$ Their lives are at the mercy of Israelite citizen-owners. God legislates freedom and slavery within the same law, which reframes the earlier gesture toward equality between citizen and alien:

When an alien resides with you in your land, you shall not oppress the alien. The alien who resides with you shall be to you as the citizen among you; you shall love the alien as yourself, for you were aliens in the land of Egypt: I am the Lord your God (Lev. 19:33-34).

The law allows Israelites to own foreigners as slaves, yet their use of slaves should not be cruel. They should not treat their slaves as they themselves were treated while enslaved in the Egyptian empire. Instead, the Israelite citizen should exercise empathetic slavery, compassionate mastery-to administer their ownership as benevolent slaveholders instead of with Egyptian brutality. Jacob Milgrom explains that the oppression prohibited in 19:33 has to do with cheating and with deceptive economic practices. ${ }^{2}$ In business dealings, aliens should be treated as citizens because they are bound up in the same beloved society, established and governed by the God who liberated Israel from the cruelty of the Egyptian form of slavery. Israel shall not take on the nature of Egypt, God declares. However, God authorizes a different kind of slave society—a reformed institution, perhaps, but a slaveholding community nonetheless, in which genealogical difference determines the line between alien and citizen, the distinction that encodes the legal status of people who may be enslaved without end. The citizen remains the citizen; the alien remains the alien. ${ }^{3}$ David and Solomon operate within the contours of the law when they issue censuses of their populations, taking stock of the foreigners, calculating the economic value of their slave labor. Their political theology trades on the difference between citizen and alien, a distinction which—if modern interpreters build immigration recommendations from these texts-furnishes a biblical world suitable for the racialized formation of the nation-state.

The insidious procedures of slavery sneak their way into political theologies when contemporary debates about the status of immigrants in nation-states turn to these Scriptures. The citizen/alien political structure inherent to these biblical passages fits too easily within the modern state, a form of peoplehood built on the juridical formulations necessary to allow for the plunder of enslaved populations, where citizenship makes possible-as its flipside, its negative image, as what it is not-the categorization people as alien, as outside the legal framework of belonging, as beyond the rights and privileges of the law, as foreigners without governmental representation. ${ }^{4}$ Thus the citizen

\footnotetext{
"The assumption here is that the alien is a chattel-slave, not a debt-slave" (Milgrom 2001, p. 2230).

(Milgrom 2000, p. 1705).

(Milgrom 2000, pp. 1705-6).

As Justice Byron White opined in the Cabell v. Chavez-Salido (1982) decision: “The exclusion of aliens from basic governmental processes is not a deficiency ... but a necessary consequence of the community's process of political self-definition.
} 
produces the slave. Reading these biblical texts in this contemporary context confronts us with how political visions harbor legacies of enslavement. Political theology cannot escape the mechanisms of slavery lurking within its proposals for statecraft. ${ }^{5}$ The structures of citizenship, I argue, rely on the production of immigrant detainees. The status of the U.S. citizen requires immigration detention centers and strategies of deportation as part of political mechanisms of modern enslavement.

\section{Regulated Bodies}

In Michel Foucault's genealogy of the modern state, in his Collège de France lectures, state power emerges as a health science concerned with the racial hygiene of the social body: a politics of life concerned with "material and moral hygiene ... the sense of social integration." ${ }^{6}$ The modern state administers a biopolitical power of governmentality that surveils human relations and tracks the morphology of population flows, all for the purpose of producing a racially manufactured society that masquerades as ordered according to nature, as organic to the logic of anthropological formation. The function of the government becomes a presumed naturalism: to analyze the population in order to discern its organic course in the world and organize people accordingly, for the sake of the integrated health of the whole of society. "The fundamental objective of governmentality will be mechanisms of security," Foucault remarks, "it will be state intervention with the essential function of ensuring the security of the natural phenomena ... of processes intrinsic to population." ${ }^{7}$ The putative rationale for such interventions is hygienic, the wellbeing of the body politic-as if the policing functions of the state are medical procedures, the police as health professionals entrusted with the flourishing of the collective body, to surgically remove diseased members and quarantine others. The prison is a hospital. Detention is amputation. "Growth within order and all positive functions will be assured by a whole series of institutions, apparatuses, mechanisms, and so on, and then the elimination of disorder will be the function of the police." ${ }^{\prime 8}$

Modern statecraft exists as a system of homeostasis, established to manage the multitude, to govern a people within a geographic domain, to subdue the profligacy of human beings as life transgresses borders-to identify and contain "heterogeneous elements," as Foucault puts it, "the idea that foreigners have infiltrated this society, the theme of the deviants who are this society's by-products." ${ }^{\prime 9}$ Foreigners threaten the demographic equilibrium, an alien presence endangering

Self-government, whether direct or through representatives, begins by defining the scope of the community of the governed and thus the governors as well: Aliens are by definition those outside of this community." Quoted in (Stumpf 2006, p. 412).

As Carl Schmitt—at the dawn of the twentieth century-claimed, "all significant concepts of the modern theory of the state are secularized theological concepts" (Schmitt 1985, p. 36). For Schmitt, the religious legacy of political theory justified the fascist abrogation of democratic institutions for the sake of order, for the sake of national security; the sovereign decides on a state of exception to the law in order to protect the body politic from chaos, which involves the fundamental political distinction: that is, the friend/enemy distinction: "The specific political distinction to which political actions and motives can be reduced is that between friend and enemy," Schmitt wrote, where the nature of the enemy becomes "existentially something different and alien" (Schmitt 2007, pp. 26-27). Giorgio Agamben explores how Schmittian political theory produces the categories of friend and enemy as internal to the logic of sovereignty (Agamben 1998). The sovereign produces the homo sacer, a bare life, stripped of status within the political order (p. 100): the sovereign and the bare life, each at the opposite extremity of the law's domain from the other. "The paradox of sovereignty consists in the fact the sovereign is, at the same time, outside and inside the juridical order" (p. 15); and "He who has been banned is not, in fact, simply set outside the law and made indifferent to it but rather abandoned by it, that is exposed and threatened on the threshold in which life and law, outside and inside, become indistinguishable" (p. 29). In the same way that Agamben explains the interlocked nature of the sovereign and the homo sacer ("the production of bare life is the originary activity of sovereignty" [p. 83]), I describe citizenship as dependant upon the category of alien as its opposite-the citizen as saved from the plight of detainees, the citizen whose political identity depends on its others. The guarantees of citizenship are a kind of salvation from the conditions of immigrant detention: There but by the grace of the state go I, says the citizen when confronted with the news of another ICE raid.

6 (Foucault 2010, p. 157, n. 62).

7 (Foucault 2009, p. 353).

8 (Foucault 2009, p. 354).

9 (Foucault 2003, p. 81). 
a peoplehood's cohesion, the biological integrity of a racial state. ${ }^{10}$ "The modern state, in short, is nothing less than a racial state,"11 according to David Theo Goldberg who tracks the legacy of European nation-building as colonialism migrated to North America and morphed into the racial logic of the United States-a political institution that homogenizes otherness as part of rendering someone able to reside within its geographic boundaries: "the state inherently is the institutionalization of homogeneity," Goldberg argues. "This homogenizing logic is internal to administration and governmentality." 12 In his 1841 Lectures on Colonialism and Colonies, Herman Merivale summarized the homogenizing strategy of the modern state as amalgamate or perish: "amalgamation, by some means or other, is the only possible euthanasia of savage communities." ${ }^{13}$ The difference that the state names as race becomes a threat when a people's otherness resists assimilation into the imposed categories of belonging. Goldberg renders Merivale's vision as "perish through amalgamation." In other words, racial difference becomes a problem for statecraft when heterogeneous elements refuse authorized classifications and the social stratifications that accompany such coding, all in an attempt to structure the world, to provide social coherence, to render people governable. ${ }^{14}$ State power depends on representation - "fabricating homogeneity," "the nationalizing drive to a fantasized homogeneity" - to claim to speak on behalf of its constituent parts. ${ }^{15}$ The state is "a semblance of coherence, a singularity of style and voice, a common language and mode, the shadow of an institutional sphere in the face of prolific heterogeneous messiness." 16 Governmentality names the force at work throughout a people to fabricate a collectivity, to police the bounds of a national identity within which some belong and others are unrepresentable. The state is an apparatus of capture, writing legal fictions onto a social landscape awash with diffused lives, people on the move through political boundaries and racial constructions. ${ }^{17}$ "Those falling outside of the assimilative categories," Goldberg writes, "are cognizable only as strangers or criminals"18 — and criminal because strange, the criminalization of foreignness which results in the designation of people as "removable in the state's name to a place beyond its borders or to institutionalized holding pens such as prisons." ${ }^{\prime 19}$ Detention centers have become the place beyond yet within U.S. borders, a quarantine facility for people categorized as foreign, as alien, as unlawful residents and therefore dangerous to nationalist identity.

Political administrations-from David and Solomon's kingdoms to modern nation-states—take stock of populations, determining whom to include and exclude as members under their laws and within their borders: to number the citizens and aliens as part of the bureaucratic oversight of society. The census is an exercise in coloniality, a mechanism of "racial administrology" for the modern state, as David Theo Goldberg names it, "to track the threat of heterogeneity." 20 To number a population is

10 This healthcare metaphor exceeds the metaphorical as contemporary nationalists correlate the arrival of foreigners to public health hazards: "People with tremendous medical difficulty and medical problems are pouring in," President Donald Trump remarked at an Oval office meeting on 11 December 2018, "and in many cases its contagious-they are pouring into our country" (Trump 2018). Immigrants, according to the U.S. president, are a communicable disease threatening the integrity of the body politic.

1 (Goldberg 2002, p. 2).

(Goldberg 2002, p. 30).

(Goldberg 2002, p. 82).

(Goldberg 2002, p. 94). "Modern states invoke the classifying of races as offering structure to worlds seen as if by nature." (Goldberg 2002, pp. 120, 140).

(Goldberg 2002, p. 120).

7 "Apparatus of capture," as a concept, comes from Gilles Deleuze and Félix Guattari, A Thousand Plateaus: Capitalism and Schizophrenia, "7000 B.C.: Apparatus of Capture" (Deleuze and Guattari 1987, chp. 13).

18 (Goldberg 2002, p. 140).

19 (Goldberg 2002, p. 152).

20 (Goldberg 2002, pp. 188, 190). "[R]acial states define populations into racially identified groups, and they do so more or less formally through census taking, law, and policy, in and through bureaucratic forms, and administrative practices" (p. 110). "Emerging out of colonial regimes, the modern census developed as a more or less comprehensive state mechanism to map population size, shape, distribution, quality and flow of labor supply, taxation and conscription pools, political representation, voter predictability, and the necessities of population reproduction" (p. 189). Cf. (Goldberg 1997): "Conformity and the uniformity that are both its products and presuppositions are manufactured by silencing and rendering invisible or placing outside the margins of the form the data of pure heterogeneity" (pp. 31-32). 
to establish a "static nature." A census "freezes what is historically in process" as part of a "stocktaking of the country's human assets, of the state's population capital." 21 The U.S. Department of Homeland Security-now that it has subsumed the immigration system-extends this colonial impulse to a transnational body politic as it surveils populations, harvesting biometric data, affixing identities to birthplaces, all as part of a nationalist agenda to regulate migratory patterns. ${ }^{22}$

\section{5 October 2018: Eloy, Arizona}

The concrete edifice looms on the horizon-a stark, white structure jutting up from a patchwork of green cotton fields and brown desert soil. Soon we see the sheets of fencing around the perimeter, then the sign marking the entrance: "CoreCivic Eloy Detention Center, a Federal Contract Facility of the U.S. Department of Homeland Security." We turn into the parking lot where the four of us pile out of the car and walk to the main entryway. As we wait for the guards to unlock the gates, an organizer from Mariposas Sin Fronteras—an immigrant justice organization in Tucson, AZ-hands me the list of detainees I will visit during the two hours we are allowed inside the prison. An invisible hand clicks open the first gate with a loud buzz, allowing us to congregate in the intermediate enclosure. The gate shuts behind us as cameras focus on our faces, scrutinizing our identities. After the visual inspection, the next gate opens and lets us into the facility. The guards check our IDs as we pass through the metal detector, making our way to the waiting room. Women dressed in the standard issue prison uniform empty waste bins into their trash carts. A bulletin board on the wall indicates the current population of the detention center: 1405 .

A guard escorts us through metal doors-sliding open in front of us, then locking behind us-to the visitation room where detainees sit in rows of plastic patio chairs. Some wear green clothes, others brown, a few blue-the colors indicating each person's level of privileges while incarcerated. All wear the same black shoes with velcro straps. I sit in an open booth on the other side of the room, waiting for an officer to call out the names of the people on my list. Edalia meets with me first. She crossed the border last month with her daughter and son. They fled El Salvador, seeking asylum from the police who had killed her oldest son two years ago. They soon threatened her because she would not keep silent-an outspoken mother, pleading for justice. When Immigration and Customs Enforcement officers captured her and her two remaining children, she was sent to the Eloy facility along with her daughter. The two of them share a cell. "Pero mi hijo, mi niñito," she says, dropping her head into her hands, then rubbing the creases furrowed into her forehead. A tear slides down her cheek. Others follow, pouring down, cresting her lip. Her chin quivers as she explains that they took away her son, sending him to another facility, unknown to her. "No puedo dormir," she tells me, "por las pesadillas." In her nightmares, U.S. officials deport her son, and Salvadoran police kill him as soon as he returns home. She can't talk anymore, she tells me, because she's overwhelmed with grief-but before she returns to her cellblock, she asks me to pray.

In the booth behind me I overhear an immigrant justice advocate ask a young man a series of questions, one after another, in Spanish: When and where did the border patrol pick you up? When was the last time you saw your child, before they took him away? Do you remember the name of the first facility where you were held? I assemble the fragments of conversation into a scene: one night two months ago this father crossed the border with his child into California where border patrol agents apprehended them.

21 (Goldberg 1997, pp. 32, 33). In his chapter on "Census, Map, Museum," Benedict Anderson makes similar observations-from another context-about the emergence of the census as a colonial tool to calculate the value of human populations: "For the colonial state did not merely aspire to create, under its control, a human landscape of perfect visibility; the condition of this 'visibility' was that everyone, everything, had (as it were) a serial number. This style of imagining did not come out of thin air. It was the product of ... the deep driving power of capitalism" (Anderson 2006, p. 190).

22 As Michel Foucault has argued, knowledge and power are intertwined. Regarding biometric data, in his Security, Territory, Population lectures, Foucault notes that demography—as "an apparatus of knowledge" —is "an essential dimension of the exercise of power" related to the function of policing: "the first object of police is the number of citizens" (Foucault 2009, pp. 275,324$)$. 
The father hasn't seen his daughter since then. "El veinticuatro de agosto," he says. He remembers the date. He can't forget how the desert night became an abyss that devoured his soul.

Soon the guard calls out the next person on my visitation list. "Josué Martínez," his name echoes from concrete wall to concrete wall. A youth stands up from his chair and walks over to me. As soon as we shake hands, before any introductions, he begins to tell me his story-not just of "el camino," the treacherous journey across border after border, from Honduras to the United States, but his story from the beginning of his life, from the nascent recesses of his memories, from what he's been able to piece together about himself. "No sé lo que quiero saber," he explains. "Sólo sé lo que quiero olvidar." In recounting story after story, he grasps at the threads of his life, inviting me to follow strands of narratives as he weaves a patchwork identity-to offer me a sense of his life from all that he has tried to remember and forget.

"Todo lo que he conocido es sufrimiento." His mother adopted him from the city dump-that's where she heard an infant's cries, a newborn screaming from a crevice between two mounds of trash. But he doesn't blame his biological parents, he tells me, they must have been poor and desperate, because no one throws away a child without an unthinkable reason, without agony and heartbreak. A woman found him swaddled in rags, discarded. "Ella no era normal, pero me amaba, me cuidaba." She wasn't normal, something wasn't right in her head, something different about her mind. She wouldn't talk to people, he says, only to the stray animals at the dump and in the streets, each with their own name- the birds were her closest friends. She picked me up from the trash, where I was abandoned, he tells me, and she became my mother-I became her son through her love. She died when he was a kid, before his adolescence. “¿Cómo se llamaba ella?” I ask. "El único nombre que yo sabía era Madre," he replies. Martínez never knew her given name; he knew her only as mamá. She died in 2008. “¿Cuántos años tenías?" I ask him how old he was when she died. "No sé. Nunca he conocido mi edad. Mi vida nunca ha sido documentada. No hay papeles que digan que existo." He knows that he was only a child but he doesn't know his age at the time. Without a birth certificate, he has never known how to count his years. No documents register his existence in official databases. Roman Catholic nuns, who welcomed him into their reading and writing classes for homeless children, gave him a name. When the U.S. Border Patrol took him into custody a few months ago, that was the first time a government attached a name to his body, his life now documented as an undocumented immigrant. After a couple of months in an ICE detention center for youth, Josué tells me, a guard escorted him to an appointment with the facility dentist who determined that he had turned eighteen years old this past summer and therefore should be transferred to an adult facility. He's been here ever since, waiting for an immigration judge to decide his fate-either for his deportation back to the community where gangs threatened his life, or for his release to a faith-based organization that offered to connect him to a household here in the U.S. Now that he was no longer considered a youth, the immigration system was in no hurry to decide his asylum case. ${ }^{23}$

\section{Christianity for Slave Societies}

Detention centers-as part of the deportation system, the shadow side of citizenship ${ }^{24}$-dehumanize people, stripping migrants of juridical standing, and therefore rendering them vulnerable to abuse, subject to the blunt mechanisms of state power. Attempts a reform, based on Levitical legislation, do not escape the fundamental logic of the nation-state's reliance on the distinction between citizen and alien. Such biblical arguments end up suffusing the conceptual infrastructure of the state with a political theology befitting of slave societies. This is

23 Since he is a minor, I have provided "Josué" as a pseudonym even though he gave me permission to tell his story.

24 Citizens are provided, in Goldberg's phrasing, "the mirror of their negation, of what they took themselves not to be" (Goldberg 2002, p. 178). 
not a new development. Christian discourse has always worked in, with, and under pro-slavery social institutions.

Scriptural imaginations-and the biblical interpretations enfleshed through ecclesial institutions-pervade political visions of Western statecraft. Medieval jurists in Europe reworked theological discourses as they forged the shape of civic authority for generations to come. "[T]he jurist transferred to the Prince and the state the most important social, organic, and corporational elements normally serving to explain the relations between Christ and the Church," Ernst H. Kantorowicz shows in his tome, The King's Two Bodies: A Study in Mediaeval Political Theology. ${ }^{25}$ He tracks the history of European jurists as they appropriated theological discussions of the corpus mysticum for their use in developing the conceptual apparatus to explain the body politic: that is, "the change from the Pauline corpus Christi to the mediaeval corpus ecclesiae mysticum, thence to the corpus reipublicae mysticum which was equated with the corpus morale et politicum of the commonwealth." 26 Theological formulations and scriptural rationales have always been close at hand as justifications for the politics of the state in Western societies.

In Fort Wayne, Indiana on 14 June 2018, when U.S. Attorney General Jeff Sessions defended President Donald Trump's immigration policy that led to separating undocumented families captured in the deserts north of the U.S.-Mexico border, Sessions turned to biblical theology in defense of the administration's decision:

I have put in a place a zero tolerance policy for illegal entry on our southwest border. If you cross the southwest border unlawfully, then we will prosecute you. It's that simple ... Illegal entry is a crime. It should be and must be if you are going to have a legal system and have any limits whatsoever. Persons who violate the law are subject to prosecution. If you violate the law, you subject yourself to prosecution. I would cite you to the apostle Paul and his clear and wise command in Romans 13 to obey the laws of the government because God has ordained the government for his purposes. Orderly and lawful processes are good in themselves. Consistent fair application of law is in itself a good a moral thing and it protects the weak, it protects the lawful. Our policies that can result in short term separation of families is not unusual or unjustified. ${ }^{27}$

The attorney general's scriptural reasoning belongs to a long history of political theology deployed in service to governmental power. The Wittenberg professor, Martin Luther, for example, in his 1525 theological attack on the peasants who refused to submit to royal authority, cited Romans 13:1-4 as authorization for their persecution:

'Let everyone be subject unto the higher powers.' Because they are breaking this obedience, and are setting themselves against the higher powers, willfully and with violence, they have forfeited body and soul, as faithless, perjured, lying, disobedient knaves and scoundrels are wont to do. St. Paul passed this judgment on them in Romans XIII when he said, that they who resist the power will bring a judgment upon themselves. This saying will smite the peasants sooner or later, for it is God's will that faith be kept and duty done. ${ }^{28}$

Sessions, like Luther before him, turned to biblical sources for political rhetoric to buttress the power of his administration's authority, to legitimate his dominion over others, to bless his government's rightful subjection of a population. In the United States, the secular is always being re-imbued with the theological.

\footnotetext{
(Kantorowicz 1957, p. 218).

(Kantorowicz 1957, p. 506).

See (Jacobs 2018).

(Luther 1974, pp. 121-26).
} 
There are other voices, of course - the losers of history, the underside of societies, the exploited masses-who read the Bible against the powerful. Thomas Müntzer, for example, responded to Luther's exegesis of Romans 13 by using the same text to explain why royal authorities could no longer claim the imprimatur of God. "If the authorities seek to render a perverted judgment," Müntzer argued, "the Christians present should deny this judgment as wrong and not tolerate it." ${ }^{29}$ Since "rulers are not a terror to good conduct" (Rom. 13:3), they reveal that God has not in fact ordained their authority when they persecute the innocent-thus, Müntzer reasoned, "the sword should be taken from them." 30

The give and take of these disputes reflect the back and forth within the Bible itself about the power to govern. There is an ambivalence written into the Scriptures about God's authorization of a person or an institution to have power over another.

On the one hand, in Romans 13 the apostle Paul exhorts his people to respect the political establishment's laws and officials, "for there is no authority except from God, and those authorities that exist have been instituted by God" (Rom. 13:1; cf. 1 Peter 2:13-14). In his first letter to the church in Corinth, Paul calls for an acceptance of the imperial order in its dependence on chattel slavery- “Were you a slave when called? Do not be concerned about it" (1 Cor. 7:21). The world of the Roman citizen depended on the pacification of enslaved peoples; a functional empire always depends on oppressed people who are resigned to their subjugation. Paul speaks as someone who benefits from his status as a Roman citizen, endowed with rights and privileges from the political system. "In whatever condition you were called, brothers and sisters, there remain with God" (1 Cor. 7:24). No need for desperation, no need for rebellion, no need for revolution- " for the present form of this world is passing away" (1 Cor. 7:31). Instead, he offers people enslaved by their Christian slaveholders an interim ethics of longsuffering, of patient endurance as the cosmos shifts according to the liberation established in Christ's forensic atonement, which Paul seemed to have assumed would soon be fully accomplished. In the meantime early Christian leaders-channeling Paul's guidance on a lifestyle according to the gospel—commanded the obedience of enslaved members of the church: "Slaves, obey your earthly masters with fear and trembling, in singleness of heart, as you obey Christ; not only while being watched, and in order to please them, but as slaves of Christ, doing the will of God from the heart" (Ephesians 6:5-6; cf. Colossians 3:22-24 and 1 Timothy 6:1-2). ${ }^{31}$

On the other hand, biblical texts depict governing institutions and the social order as under the dominion of satanic forces. In Luke's Gospel, when the devil tempts Jesus in the wilderness, the premise of the narrative is that political authorities are puppet regimes, that evil powers exercise sovereignty over earthly rulers, that the devil lurks behind the scenes. "Then the devil led him up and showed him in an instant all the kingdoms of the world. And the devil said to him, 'To you I will give their glory and all this authority, for it has been given over to me, and I give it to anyone I please" (Luke 4:5-6). Jesus does not question the devil's presumption of control; he instead refuses the offer. In the book of Revelation, when the seer-exiled to the island of Patmos—reveals the spiritual dimensions of the political order, he depicts the Roman Empire as a demonic beast. "Then the dragon took his stand on the seashore. And I saw a beast rising out of the sea" (Rev. 12:18-13:1). The symbolism

29 (Müntzer 1991a, p. 80).

30 (Müntzer 1991b, p. 30). "But for this use of the sword to occur as it should and in the right manner, our dear fathers who confess Christ with me-that is, the princes—should do it. But if they do not do it, then the sword will be taken away from them."

31 (Glancy 2002, pp. 142-43, 147): "The household codes articulated a strategy that Christian slaveholders could use to pacify members of their households ... The household codes identified submission and obedience as the highest virtues that slaves could attain. Slavery was thus perceived as a kind of moral training ... The Pastoral epistles represent slaveholder morality as compatible and possibly synonymous with Christian morality ... By teaching slaves that honoring their owners was part of their Christian obligation, 1 Timothy sanctified slaveholder morality beyond the standard claims of the Greco-Roman ethos." 
unmasks the beastly quality of the imperial reign of Rome, built on a Mediterranean seashore, a base from which a monstrous administration grasps the livelihood of people throughout the region. ${ }^{32}$

The Bible is a polyphonic document, preserving discordant political theologies. Scriptures are not of one mind. Those pages do not offer resolution for arguments about governmentality; instead these holy texts are a record of political impulses as the people of God discerned how to participate in their variegated worlds. The archives of biblical interpretation put on display the ideological commitments at work in readers' scriptural imaginations.

In other words, Jeff Sessions stands in a certain interpretive community-across time and place-that amplifies the voices within the Scriptures that justify his political vision while filtering out the others. He did not misread the Bible when he claimed scriptural warrant for his anti-immigrant policies. He chose a biblical imagination rooted in pro-establishment texts, a theological tradition enfleshed in pro-slavery social orders from the first centuries of the church to the modern era. "Who among you would say to your slave who has just come in from plowing or tending sheep in the field," Jesus teaches his disciples, "Come here at once and take your place at the table?" (Luke 17:7)—a text assuming that members of the Lucan community owned slaves, that members of the audience could hear themselves addressed by Jesus when he referred to "your slave." ${ }^{33}$ As Jennifer A. Glancy has documented, the Scriptures of the early church provided ample permission for slaveholding societies. ${ }^{34}$ "We ought not to withdraw slaves from the service of their masters," John Chrysostom, archbishop of Constantinople, preached in the fourth century. "For if Paul ... was unwilling to detain Onesimus, so useful and serviceable to minister to himself, without the consent of his master, much less ought we to act." ${ }^{35}$ Church communities were told not to harbor runaway slaves, for, as the apostle Paul commended, "so far as it depends on you, live peaceably with all" (Rom. 12:18)—and peace for the "all" did not include liberation for people enslaved by Roman citizens. To declare that there was "no longer slave or free" (Gal. 3:28) became a description of a spiritual reality (even Paul himself allowed master-slave relationships to persist), an announcement that such categories did not affect a person's access to God's heavenly salvation rather than a call to deconstruct the contemporary socio-political caste system. Leaders in the early church did not want to disturb the peace of the social order. Thus Basil of Caesarea instructed the communities in Cappadocia under his bishopric: "As for those slaves who are under the yoke and flee to religious communities, it is necessary to admonish and improve them and send them back to their masters." ${ }^{\prime 36}$ Everyone should remain in their station in life, under the dominion of whatever institutions are already in place-for those authorities that exist have been established by God, and therefore should be respected and obeyed. And-according to the dictates of the first-century teachings collected in the Didache - as part of their morality, slaveholding Christians should exercise restraint in their control over their slaves: "You will not command in your bitterness your slave or your slave girl." ${ }^{\prime 37}$ Slaveholding was acceptable in the church as long as Christian slaveholders practiced self-control in their domination of others.

From epoch to epoch slave societies evolve and mutate, developing into forms of life that befit political and economic systems-and Christian interpretive communities defend each iteration of

32 For the conditions of enslavement under the Roman Empire, see (Harris 1999, pp. 62-75).

33 (Glancy 2002, p. 128): "In the only extant version of this parable, Jesus asks the hearer explicitly to identify with the slaveholder who benefits from the labor of the slave ... What may ultimately be most challenging to New Testament critics is to confront the degree to which the slave parables undergird the horizon of normalcy and reinforce other evidence concerning the practice and ideology of slavery in the early Roman Empire." Cf. Rubén Rosario Rodríguez, Racism and God-Talk: A Latino/A Perspective: "none of the Gospel narratives ever depict Jesus in conversation with slaves, even though he is shown transgressing other social boundaries ... Not only does Jesus remain silent about an institution that at its core defaces the image of God in all humanity (Gen. 1:27), he then utilizes slavery as the model for proper obedience to the Word of God" (Rodríguez 2008, p. 143).

34 (Glancy 2002, p. 131): "Some Christian slaveholders had fewer slaves and some Christian slaveholders had more slaves ... but the fact that Christians owned slaves was a matter of public record and not of contention nor controversy."

35 (Glancy 2002, p. 91).

36 (Glancy 2002, p. 90).

37 (Glancy 2002, p. 151). 
servitude. From chattel slavery to convict-leasing to global economic bondage, the mechanisms of subjugation morph to fit the shape of new contexts, subsisting on the labor, the power, the vitality of people within the purview of the structures of governing, populations within the reach of statecraft's policing function. While each apparatus of enslavement differs from one to another according to historical context, European slaveholders in their North American colonies-who built the United States on the labor of enslaved peoples-developed justifications for slaveholding from the biblical world, from the Scriptures: Christians of one generation claiming the theological legacy of Christians from previous generation, establishing over time a pro-slavery interpretive tradition. ${ }^{38}$ In 1858, as part of his defense for slavery, George D. Armstrong offered biblical exegesis: "In our examination of what the New Testament teaches on the subject of slavery," Armstrong summarized, "the Apostles frequently enjoin the relative duties of master and slave ... [and] received slaveholders into the Christian church, and continued them therein, without giving any intimation, either at the time of their reception or afterwards, that slaveholding was a sin or offence." ${ }^{39}$ After the Civil War, this system of chattel slavery reformed itself into the U.S. carceral society. "The Thirteenth Amendment ensnares as it emancipates," Joy James writes, "The old plantation was a prison; and the new prison is a plantation." 40 The same constitutional amendment that abolished slavery also authorized the use of convicts as slave labor-“Neither slavery nor involuntary servitude, except as a punishment for a crime whereof the party shall have been duly convicted, shall exist within the United States" - thus the readjustment of antebellum slavery into what has become modern incarceration. The one is the legacy of the other, not as an exact duplication but a transmutation-a continuation by other means, as Angela Y. Davis has argued: “Convict leasing was a totalitarian effort to control black labor in the post-Emancipation era and it served as a symbolic reminder to black people that slavery had not been fully disestablished." ${ }^{41}$ All along the way, as incarceration became internal to the logic of U.S. democracy, Christians turned to the Scriptures for theologies of punishment. Davis mentions the role of religious reformers in providing theological rationalizations for the penitentiary, as opposed to the cruelty of corporal punishment ${ }^{42}$-a reality that Jennifer Graber recounts in her study of the influence of Christianity on the emergence of the U.S. penitentiary. ${ }^{43}$

Christians throughout history have returned to Scripture for their pro-slavery theologies, to the Bible as a source for peaceable living, as guidance for a lifestyle of non-disruption to the social order, a political theology of submission to the governing authorities whose power flows from God's dominion, from Christ's headship- "for in him all things in heaven and on earth were created, things visible and invisible, whether thrones or dominions or rulers or powers" (Col. 1:16). The U.S. government-through the justifications of Attorney General Jeff Sessions-has extended this trajectory within biblical theology to police immigrants as the carceral complex expands its scope to specialize in detaining non-citizens, migrants without documentation, an identity produced by our modern global political economy. The newness of our postmodern condition belies the old, persisting economic structure of oppression, of domination: "the reflex and the concomitant of yet another systemic modification of capitalism itself," which includes, as Fredric Jameson observes, "the new international division of labor ... the flight of production to advanced Third World areas ... and gentrification on a

\footnotetext{
(Glancy 1998, pp. 465-82; Martin 1991, pp. 206-31).

41 (Davis 1998a, pp. 74-95). "In constructing prisoners as human beings who deserved subjugation to slavery, the Constitution allowed for a further, more elusive linkage of prison and slavery, namely the criminalization of former slaves" (Davis 1998b, pp. 96-107). Cf. (Davis 2003, chp. 2): "Slavery, Civil Rights, and Abolitionist Perspectives Toward Prison."

42 (Davis 1998b, p. 103)

43 (Graber 2011). “The Reverend John Stanford kept a copy of the first sermon he preached at Newgate. He took his text from Isaiah 48:10: 'Behold, I have refined thee, but not with silver; I have chosen thee in the furnace of affliction' ... The prison was to be a furnace of affliction, a well-running, orderly machine designed to put great pressure on inmates, who would then emerge transformed by the experience" (pp. 54-55).
} 
now-global scale." 44 The global order is a "patrón colonial de poder," in Aníbal Quijano's words-a colonial matrix of power, a structure of domination that emerged as European powers enslaved peoples from the continent of Africa to use their bodies as machines for civilization-building while also pursuing a genocidal exploitation of land and resources in the Americas. ${ }^{45}$ This matrix of forces has configured our world for European powers-and their heirs in the Americas-to extract labor and resources from populations and geographies throughout the globe. ${ }^{46}$ The master-slave relationship has been globalized through the violent economics of Western powers. ${ }^{47}$

The United States now harbors these forces, which are engaged in the ongoing colonization of the earth. Military interventions and diplomatic negotiations work in conjunction with the business interests of conglomerates as they extract capital from the two-thirds world. In the Americas, the United States has enslaved the economies of neighboring countries. "Latin America is the region of open veins," as Eduardo Galeano depicted the intra-American relationships,

Everything, from the discovery until our times, has always been transmutated into European—or later United States—capital, and as such has accumulated in distant centers of power. Everything: the soil, its fruits and its mineral-rich depths, the people and their capacity to work and to consume, natural resources and human resources. Production methods and class structure have been successively determined from outside for each area by meshing it into the universal gearbox of capitalism. To each area has been assigned a function, always for the benefit of foreign metropolis of the moment, and the endless chain of dependency has been endlessly extended. ${ }^{48}$

Just as the plantation became the prison, the plantation economy became the globalized economic system, operated by "mechanisms of plunder." 49 The policing of migrants enacts structures of confinement, allowing U.S. society to plunder the wealth of others across borders, thus devastating communities while fencing out people desperate for the livelihood stolen from them. Efforts at border security enslave unwanted populations to a subsistent existence, rendering people as

44 (Jameson 1991, pp. xii, xix).

45 (Mignolo 2011, pp. 7-8).

46 (Quijano 2008, pp. 181-224).

47 In her book Carceral Capitalism, Jackie Wang describes—borrowing an image from Karl Marx-the global economic order as vampire-like, "a parasitic relationship" (Wang 2018, p. 107). Wang develops this analysis of the global economic sovereignty from Rosa Luxemburg's observations at the beginning of the twentieth century: "capital ransacks the whole planet, procuring means of production from every crevice of the Earth, snatching up or acquiring them from civilizations of all stages and all forms of society" (Luxemburg 2015; Wang 2018, p. 108).

48 (Galeano 1997, p. 2).

49 (Galeano 1997, p. 8). The plot of Galeano's historical narrative of the exploitation of the Americas culminates with a focus on plunder, "despojo" in the original Spanish. His final chapter is titled, "The Contemporary Structure of Plunder." The legacy of Europe's dual operations of enslavement and colonization is, according to Galeano, understood as the plundering of other peoples and lands, which is a central theme for Ta-Nehisi Coates' work. The word reoccurs throughout his collection of essays published as We Were Eight Years in Power: An American Tragedy (Coates 2017)—a concept that becomes a lens through which to see the original sin that birthed the United States (pp. 9, 85, 112, 114, 158, 159, 180, 181, 185, 196, 198, $204,211,214,215,222,231,250,279,324,330,341,366,367)$ : for example, “The sins of slavery did not stop with slavery. On the contrary, slavery was but the initial crime in a long tradition of crimes, of plunder even, that could be traced into the present day" (p. 158); "America begins in black plunder and white democracy, two features that are not contradictory but complementary" (p. 180). While "plunder" enables Galeano to pay attention to the nexus of European exploitation of peoples and lands and resources-including the enslavement of Africans, the conquest of civilizations, and the genocide of indigenous populations-Coates narrows his focus on the singular plunder of slavery. Writing in the late eighteenth century, the Ghanaian abolitionist Ottobah Cugoano considered the European plunder of African bodies (including his own) and the destruction of indigenous civilizations of the Americas as concomitant: "The French and English, and some other nations in Europe, as they founded settlements and colonies in West Indies, or in America ... joined hand in hand with the Portuguese and Spaniards, to rob and pillage Africa, as well as to waste and desolate the inhabitants of the Westerns continent." There is an intersectionality to this description of colonial plundering that Coates ignores. His focus allows him to set aside a whole conflux of oppressions that happened together, historically, which continue to shape our world-"the emergence of a structure of control and management of authority, economy, subjectivity, gender and sexual norms and relations," as Walter D. Mignolo argues, "that connected European initiatives, enslaved Africans, dismantled civilizations (Tawantinsuyu and Anáhuac, and the already-in-decay Maya), and encompassed the genocide in Ayiti (which Columbus baptized Hispaniola in 1492)" (Mignolo 2011, p. 7). 
indentured servants to the global economy and pawns in the political schemes of superpowers. The nationalist commitments of the United States admits the flow of capital while regulating transnational demographics by excluding foreign bodies, renaming neighbors as enemies.

"We are not going to let this country be invaded," declared Sessions on 7 May 2018 in Scottsdale, Arizona. ${ }^{50}$ "These aren't people, these are animals," President Trump ranted at a White House meeting on 15 May 2018..$^{51}$ National citizenship registers the status of a person's nature; federal policies determine the status of someone's being. Racialized societies depend on these kinds of distinctions-legal fictions, the imposition onto nature of hierarchies of being, an "ontological distinction between superior and inferior," as Michael C. Dawson observes, which "was necessary for slavery, colonialism, the theft of lands in the Americans, and genocide." These distinctions undergird a political order set up to determine sectors of populations as "disposable," people who can be "ultimately either eliminated or superexploited." 52 This context has produced the immigration detention center as a form of racialized incarceration-detention facilities built to punish runaways, to return people to their position in the caste system of the international network of exploitation, to deter migrants from fleeing their geographic enclosures and accept the conditions of domination as the facts of life. "They represent," Angela Y. Davis argues, "the increasingly global strategy of dealing with populations of people of color and immigrant populations from the countries of the Global South as surplus populations, as disposable populations." ${ }^{53}$ U.S. immigration prisons incarnate a political vision where surplus people groups are processed as enslaveable within the machinations of postmodern colonial statecraft. Detention centers are the result of the globalized slave economy, a system buttressed with Christian ideologies, with proslavery political theologies. "In whatever condition you were called, brothers and sisters, there remain with God."

\section{Obscured Nonconformists}

At the Council of Chalcedon in 451, bishops of the Western church confirmed their investment in a form of Christianity that would be good for the empire, an articulation of a faith well suited for the imperial political order-that they would maintain peaceable participation in the slave society. In the fourth canon of the Council's document, the leaders of the church reassured the governing authorities that their ecclesial institutions would not threaten the established systems of enslavement: "no slave shall be received into any monastery to become a monk against the will of his master," the bishops instructed the communities under their authority. ${ }^{54}$ The reprimand indicates that there were wayward Christian communities harboring enslaved people, providing a sanctuary of liberation from slaveholders, thus defying the dominion of masters and the dictates of ecclesial authorities.

Since the dawn of the Christian movement, church leaders allied themselves to slaveholder society. Ignatius of Antioch, for example, counsels Polycarp — his fellow bishop in Smyrna-to encourage enslaved members of the community to persevere in their servitude and to discourage church members from using congregational funds for manumission: "Do not be haughty to male slaves and female slaves," Ignatius wrote, "but let them rather endure slavery to the glory of God... Let them not desire to be set free at the Church's expense, that they be not found the slaves of desire." 55 Such admonishments seem to indicate that-in the shadows of church history, in the silences of official communications,

50 https://www.justice.gov/opa/speech/attorney-general-sessions-delivers-remarks-association-state-criminalinvestigative (accessed on 4 January 2018).

51 https://www.nytimes.com/2018/05/16/us/politics/trump-undocumented-immigrants-animals.html (accessed on 4 January 2018).

52 (Dawson 2016, pp. 143-61; Wang 2018, pp. 121-22).

53 (Davis 2016, p. 107). In her essay on "Race and Criminalization," Davis makes clear the inseparability of racism and economics, which produces social mechanisms of incarceration: "racism is more deeply embedded in socio-economic structures, and the vast populations of incarcerated people of color is dramatic evidence of the way racism systematically structures economic relations" (Davis 1998b, p. 66).

54 (Glancy 2002, p. 90).

55 (Glancy 2002, p. 152). 
among minoritian Christian collectives-communities devised schemes of liberation, unauthorized operations of redemption, ecclesially illicit activities against the political economy of slavery.

While there have always been Christianities-justified by their pro-slavery Scriptures-that support slaveholding societies, there are also disestablishment forms of Christian collectivities, minoritarian trajectories inspired by the tortured one: Jesus of Nazareth, subjected to detention and punishment, whose resurrected life looks like a foreigner, whose life beyond the tomb is categorized as a resident alien (Luke 24:18- "a paroikeō in Jerusalem"). For people who choose this kind of faith, the Messiah will come as one unknown, without a name, as of old, in a visiting room of a detention center. ${ }^{56}$

\section{Apophatic Peoplehood}

In 2 Chronicles, after Solomon's census and building projects, the Davidic kingdom begins to unravel. The rest of the book follows the storyline of an empire in collapse. After a detailed account of the temple's glories, the narrator foreshadows the kingship's ominous trajectory by referring to Solomon's burgeoning attachment to Egypt-that infamous slave-society forever seared into Israel's memory. "Solomon brought Pharaoh's daughter from the city of David to the house that he had built for her" —and he calls her "my wife" (2 Chron. 8:11). Solomon marries into the legacy of slavery, his union as a sign of what he has become: an imperial master. Not only does he enslave aliens, he treats his Israelite kin as slaves. His addiction to slave labor consumes his governance. Solomon's iron rule keeps the people silent while they undergo his mechanisms of enslavement-a silenced population, until his death. "Your father made our yoke heavy," the people complain to Solomon's heir, Rehoboam. "Now therefore lighten the hard service of your father and his heavy yoke that he placed on us, and we will serve you" (2 Chron. 10:4). They have become beasts of burden, shackled with the yoke of slavery. Rehoboam responds with a promise of bondage more brutal than Solomon's: "My father made your yoke heavy, but I will add to it; my father disciplined you with whips, but I will discipline you with scorpions" (2 Chron 10:14).

The rest of the book documents the implosion of Israel's slave society, culminating with Egypt's total control in the final chapter. What began with Solomon's dabbling with Egyptian-style slavery matures into Egyptian enslavement of the kingdom. After King Neco of Egypt exerted military domination of the land, he installed a puppet ruler "and laid on the land a tribute of one hundred talents of silver and one talent of gold" (2 Chron. 36:3). The end is like the beginning: the people as Egyptian plunder.

The United States is not the people of God. There is no divine covenant with this modern government. 2 Chronicles does not provide policy recommendations for statecraft. The narrative, instead, is a warning-a prophecy, perhaps, exposing an inclination toward enslaving people, a proclivity lurking in the shadows of governmentality enabled when the authorities take a census of aliens, when bodies are marked with legal fictions, coding some residents as citizens and others as aliens. These biblical texts offer a caution, a negative political theology, pressing toward an apophatic hope: Ezekiel's prophecy of an era when Israel's God will disorient modes of existence based on the difference between citizen and alien.

So you shall divide this land among you according to the tribes of Israel. You shall allot it as an inheritance for yourselves and for the aliens who reside among you and have begotten children among you. They shall be to you as citizens of Israel; with you they shall be allotted an inheritance among the tribes of Israel (Ezek. 47:21-22).

56 This sentence is an allusion to Albert Schweitzer-the concluding image of Jesus in The Quest of the Historical Jesus (Schweitzer 1956, p. 403): “He comes to us as One unknown, without a name, as of old, by the lake-side, He came to those men who knew Him not. He speaks to us the same word: 'Follow thou me!' and sets us to the tasks which He has to fulfill for our time. He commands. And to those who obey Him, whether they be wise or simple, He will reveal Himself in the toils, the conflicts, the sufferings which they shall pass through in His fellowship." 
The alien will be as the citizen, the foreigner as the Israelite. "To give the foreign resident outsider a share in the patrimony effectively eliminates all difference between him and the native," as Saul M. Olyan explains the significance of Ezekiel's prophecy. "[P]ersons previously classified as alien would now be incorporated into the genealogical traditions of the people, which express kinship both by blood and by acquisition." ${ }^{57}$ God's prophet calls the people to imagine a transgressive politics, the advent of a society that does not require the juridical distinction between citizen and alien. Such a world will involve a crumbling of familiar political orders and an anticipation of a body politic that trespasses through citizenship's borders, which will include the subversion of political theologies and legal theories that justify structures of enslavement.

Funding: This research received no external funding.

Conflicts of Interest: The author declares no conflict of interest.

\section{References}

Agamben, Giorgio. 1998. Homo Sacer: Sovereign Power and Bare Life. Stanford: Stanford University Press.

Anderson, Benedict. 2006. Imagined Communities: Reflections on the Origin and Spread of Nationalism. London: Verso. Coates, Ta-Nehisi. 2017. We Were Eight Years in Power: An American Tragedy. New York City: Random House.

Davis, Angela Y. 1998a. From the Prison of Slavery to the Slavery of Prison: Fredrick Douglass and the Convict Lease System. In The Angela Y. Davis Reader. Oxford: Blackwell.

Davis, Angela Y. 1998b. Racialized Punishment and Prison Abolition. In The Angela Y. Davis Reader. Oxford: Blackwell.

Davis, Angela Y. 2003. Are Prisons Obsolete? New York: Seven Stories Press.

Davis, Angela Y. 2016. Freedom Is a Constant Struggle: Ferguson, Palestine, and the Foundations of a Movement. Chicago: Haymarket Books.

Dawson, Michael C. 2016. Hidden in Plain Sight: A Note on Legitimation Crises and the Racial Order. Critical Historical Studies 3: 143-61. [CrossRef]

Deleuze, Gilles, and Félix Guattari. 1987. A Thousand Plateaus: Capitalism and Schizophrenia. Minneapolis: University of Minnesota Press.

Foucault, Michel. 2003. "Society Must Be Defended": Lectures at the Collège de France, 1975-1976. New York: Picador. Foucault, Michel. 2009. Security, Territory, Population: Lectures at the Collegge de France, 1977-1978. New York: Picador. Foucault, Michel. 2010. The Birth of Biopolitics: Lectures at the Collège de France, 1978-1979. New York: Picador.

Galeano, Eduardo. 1997. Open Veins of Latin America: Five Centuries of the Pillage of a Continent. New York: Monthly Review Press.

Glancy, Jennifer A. 1998. House Readings and Field Readings: The Discourse of Slavery and Biblical/Cultural Studies. In Biblical Studies/Cultural Studies: The Third Sheffield Colloquium. Sheffield: Sheffield Academic Press.

Glancy, Jennifer A. 2002. Slavery in Early Christianity. New York: Oxford University Press.

Goldberg, David Theo. 1997. Racial Subjects: Writing on Race in America. London: Routledge.

Goldberg, David Theo. 2002. The Racial State. Oxford: Blackwell.

57 (Olyan 2000, p. 73). Olyan notes that Ezekiel's prophecy diverges from the biblical legislation regarding the composition of Israel's peoplehood. "The assignment of patrimonial shares to resident outsiders of foreign background is a radical departure from previous practice, which viewed the foreign resident outsider and his descendants as outside the lineage-patrimony structure of Israel. Even Holiness texts that insist on the equality of the native and the circumcised resident outsider in cultic and quasi-cultic settings do not propose to integrate the resident outsider in this radical way ... In a word, this radical reform envisioned by Ezek 47:22-23 represents the granting of (fictive) kinship to the resident outsider; he becomes at last a brother rather than an other". While the prophecy imagines a divergent trajectory for Israel's body politic, the blurring of the juridical distinction between citizen and alien harkens back to the customs of integration during the early formation of Israel. "When emerging tribes fully incorporated alien groups, their incorporation was reflected in the genealogical idiom, and their alien origins were for all intents and purposes erased. The Judahite genealogical record provides the best example of this kind of radical assimilation of outsiders in early Israel. As early Judah grew, it absorbed a number of non-Israelite groups as well as the tribe of Simeon. Extant evidence suggests that Judahite groups such as the Jerahmeelites, Qenizzites, and even Zerah, Judah's second clan, were originally foreign and were absorbed into Judah's kin structure"' (p. 73). 
Graber, Jennifer. 2011. The Furnace of Affliction: Prisons \& Religion in Antebellum America. Chapel Hill: The University of Chapel Hill Press.

Harris, William V. 1999. Demography, Geography and the Sources of Roman Slaves. The Journal of Roman Studies 89: 62-75. [CrossRef]

Jacobs, Julia. 2018. Session's Use of Bible Passage to Defend Immigration Policy Draws Fire. The New York Times, June 15. Available online: https:/ /www.nytimes.com/2018/06/15/us/sessions-bible-verse-romans.html (accessed on 4 January 2019).

James, Joy. 2005. The New Abolitionists: (Neo)Slave Narratives and Contemporary Prison Writings. Albany: State University of New York Press.

Jameson, Fredric. 1991. Postmodernism, or, the Cultural Logic of Late Captialism. Durham: Duke University Press.

Kantorowicz, Ernst H. 1957. The King's Two Bodies: A Study in Mediaeval Political Theology. Princeton: Princeton University Press.

Luther, Martin. 1974. Against the Robbing and Murdering Hordes of Peasants. In Martin Luther. London: Edward Arnold \& Co.

Luxemburg, Rosa. 2015. The Complete Works of Rosa Luxemburg, Volume II. London: Verso Books.

Martin, Clarice. 1991. The Haustafeln (Household Codes) in African American Biblical Interpretation: 'Free Slaves' and 'Subordinate Women'. In Stony the Road We Trod: African American Biblical Interpretation. Minneapolis: Fortress Press.

Mignolo, Walter D. 2011. The Darker Side of Western Modernity: Global Futures, Decolonial Options. Durham: Duke University Press.

Milgrom, Jacob. 2000. Leviticus 17-22: A New Translation with Introduction and Commentary. In The Anchor Bible. New York: Doubleday.

Milgrom, Jacob. 2001. Leviticus 23-27: A New Translation with Introduction and Commentary. In The Anchor Bible. New York: Doubleday.

Müntzer, Thomas. 1991a. A Highly Provoked Defense. In The Radical Reformation. Cambridge: Cambridge University Press.

Müntzer, Thomas. 1991b. Sermon to the Princes. In The Radical Reformation. Cambridge: Cambridge University Press.

Olyan, Saul M. 2000. Rites and Rank: Hierarchy in Biblical Representations of Cult. Princeton: Princeton University Press. Quijano, Aníbal. 2008. Coloniality of Power, Eurocentrism, and Latin America. In Coloniality at Large: Latin America and the Postcolonial Debate. Durham: Duke University Press.

Rodríguez, Rubén Rosario. 2008. Racism and God-Talk: A Latino/A Perspective. New York: New York University Press.

Schmitt, Carl. 1985. Political Theology: Four Chapters on the Concept of Sovereignty. Cambridge: MIT Press.

Schmitt, Carl. 2007. The Concept of the Political. Chicago: University of Chicago Press.

Schweitzer, Albert. 1956. The Quest of the Historical Jesus. New York: MacMillan.

Stumpf, Juliet. 2006. The Crimmigration Crisis: Immigrants, Crime, and Sovereign Power. American University Law Review 56: 412.

Trump, Donald. 2018. Oval Office. December 11. Available online: https://www.whitehouse.gov/briefingsstatements / remarks-president-trump-meeting-senate-minority-leader-chuck-schumer-house-speakerdesignate-nancy-pelosi/ (accessed on 4 January 2019).

Wang, Jackie. 2018. Carceral Capitalism. South Pasadena: Semiotext(e).

(c) 2019 by the author. Licensee MDPI, Basel, Switzerland. This article is an open access article distributed under the terms and conditions of the Creative Commons Attribution (CC BY) license (http:/ / creativecommons.org/licenses/by/4.0/). 